DOI: https://doi.org/10.31933/dijms.v2i6

Received: $24^{\text {th }}$ June 2021, Revised: $25^{\text {th }}$ July 2021, Publish: $15^{\text {th }}$ August 2021

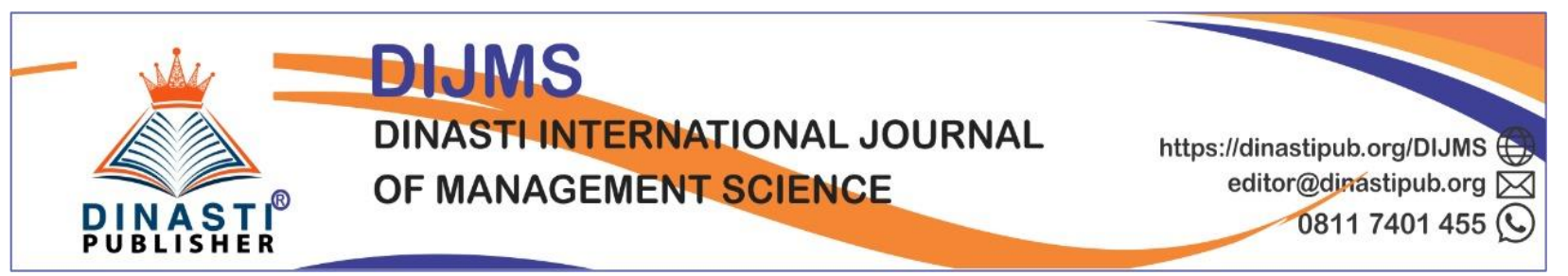

THE INFLUENCE OF LEADERSHIP STYLE, COMPETENCE AND ORGANIZATIONAL CULTURE ON CIVIL SERVENT PERFORMANCE THROUGH WORK MOTIVATION AND JOB SATISFACTION AT REGIONAL IV OFFICE BKN MAKASSAR

\author{
Misra Mahmud ${ }^{1}$, Muhtar Sapiri ${ }^{2}$, Arifin Zaidin ${ }^{3}$ \\ 1) Post Graduate Program of Universitas Terbuka, West Sulawesi, Indonesia,misramahmud11@ gmail.com \\ 2) Universitas Bosowa Makassar, South Sulawesi, Indonesia, muhtar.sapiri62@gmail.com \\ 3) Universitas Terbuka, South Sulawesi, Indonesia, arza0403@gmail.com
}

Corresponding Author: misra mahmud ${ }^{1}$

Abstract: This study aimed to analyze the direct impact of leadership style, competence, organizational culture on the employee performance of the Regional IV Office of BKN Makassar and the indirect effect through work motivation and job satisfaction. Using the slovin formula, the number of samples obtained was 90 people. To facilitate the research, observations, questionnaires and documentation were carried out. The data analysis technique used PLS analysis through the outer model, inner model, goodness of fit evaluation, hypothesis testing, and Sobel test. The study results obtained empirical findings that leadership style, competence can significantly affect the improvement of employee performance. Meanwhile, organizational culture had no noticeable impact. The mediation test results showed that the effects of leadership style and competency on employee performance through work motivation was considerable, whereas organizational culture through motivation was not. Leadership style, competence, and organizational culture through job satisfaction all have a significant impact.

Keywords: leadership style, competence, organizational culture, and employee performance

\title{
INTRODUCTION
}

The performance of civil servants who have achieved this is still considered to have not lived up to expectations. Performance is a measure of the ability of civil servants. Performance is an organisational resource development activity to achieve organisational goals (Wibowo \& Phil 2016). Therefore, performance needs to be measured with a certain period. According to Edison et al. (2016), the achievement of optimal and consistent performance has not happened by 
chance, but has been the result of careful planning and utmost effort. Real outcomes cannot be obtained without proper performance management. Edison et al. (2016) say that one's leadership style mostly determines success or failure in achieving organisational goals in managing existing resources. Leadership is the style or way the leader moves his subordinates to achieve their goals. Leadership style in an organisation is needed in building an organisation to achieve work motivation, job satisfaction, and employee performance. A good leadership style will increase motivation for employees to do work; thus, it creates a feeling of satisfaction by employees, which implicates employee performance improvement. This is based on research conducted by Nurwijayanti, et al (2019), and Rathore et al. (2017). However, Saputri \& Andayani (2018) argued that leadership has a negative and insignificant effect on employee performance, so there is a research gap in this study.

Competence becomes very useful to help organisations create a high-performance culture. It is indispensable in every human resource process, employee selection, performance management, planning and so forth (Wibowo, 2016). Raisid (2016) found that competence has a positive and significant effect on employee performance. While Adam and Kamase (2019) were unable to demonstrate that competence has a positive and significant impact on employee performance. This study then identified a research gap.

Organisational culture is a shared meaning system embraced by the members who provide organisation with other organisations (Robbins \& Judge, 2015); so that the existence of organisational culture influences the factors of work motivation, job satisfaction, and employee performance. Hasmin (2016) and Moeljahwati, et al (2016) show that organizational culture has a positive and significant impact on employee performance. But research Andi et al. (2019) founded that organizational culture has no significant impact on job satisfaction and employee performance.

Work motivation and job satisfaction affect employee performance, where Ali et al. (2016), found that work motivation had a significant impact on employee performance. Furthermore, Ezeanyim (2019) explain a linear relationship between job satisfaction and employee performance. Prahasti \& Wahyono (2018) showed that leadership style positively and significantly affects employee performance through job satisfaction. Himawan, et al., (2019) found that leadership style did not have a significant effect on employee performance mediated by job satisfaction.

Then in the mediation test, namely the impact of competence on employee performance through work motivation and job satisfaction. This is based on Aprikristanti (2020) research, which found that competence did not have significant impact on performance through motivation, where Gunawan $(2015$, p.82) found that competence had a positive and significant impact on performance through job satisfaction. Renyut, et al (2017) found that competence had a positive and significant impact on performance through job satisfaction. 
Another mediation test is the influence of organizational culture on employee performance through work motivation and job satisfaction. This is based on Yusniar's (2016) research findings that organizational culture affects employee performance through motivation. In comparison, Usman (2019) showed that job satisfaction can mediate the influence of organizational culture on performance through job satisfaction. In relation to the description above, in this study, the reason for choosing research variables, namely leadership style, competence, organizational culture, motivation, and job satisfaction with employee performance, was based on a research gap, where each previous research result that was inconsistent needs to be retested. But Haqq, (2016) which found that organization culture did not have significant impact on performance through motivation work.

Based on research a research gap and the phenomena of Civil servant performance that occurred. This is what encouraged researchers to conduct research with the title: The Influence of Leadership Style, Competence and Organizational Culture on Civil Servant Performance Through Work Motivation and Job Satisfaction at Regional IV Office of BKN Makassar.

\section{Formulation of The Problem}

The problem discussed in this research is "Does leadership style, competence, organizational culture, work motivation, and job satisfaction directly affect employee performance at Regional Office IV BKN Makassar, and whether leadership style, competence, organizational culture, indirectly to employee performance at Regional IV Office of BKN Makassar through work motivation and job satisfaction.

\section{Objective of The Research}

The study aimed to examine and determine the direct influence of the variables of leadership style, competence, organizational culture, work motivation, job satisfaction on employee performance at Regional IV Office of BKN Makassar, as well as the indirect influence of the variables Leadership Style, Competence, Organizational Culture on employee performance at Regional IV Office of BKN Makassar through work motivation and job satisfaction.

\section{LITERATURE REVIEW}

\section{Leadership Style}

The leadership style that has been theorized so far is more directed at how leaders can influence followers to voluntarily take various joint actions ordered by the leader without feeling that they are pressured to achieve organisational goals. According to Rivai \& Mulyadi (2012), leadership style is a collection of qualities utilized by leaders to influence subordinates to achieve organisational goals; alternatively, leadership style may be defined as a pattern of behavior and methods that a leader prefers and frequently employs.

\section{Competence}

To achieve organisational goals successfully, human resources, leaders, and subordinates are needed who have the competence to provide the best results in carrying out their work. 
Competence is the ability of human resources in various specific fields and is shown by various characteristics. Sedarmayanti (2018) says that competence is a description of the existing ability to carry out the various tasks required by a particular job, in the form of skills and abilities that have been possessed by an individual so that people can carry out the various tasks required

\section{Organisational Culture}

Mulyadi (2015) says that organisational culture is a basic pattern found or developed by a certain group, such as studying dealing with problems that are adapted from outside and integration from within, which has been going quite well, legally recognized and therefore that needs to be thought about and felt concerning these problems.

Organisational culture indicators, according to Busro (2018) detailed several indicators, including:

1. Diligence, a person's behavior in dealing with something seriously and continuously.

2. Sincerity, the sincerity to do something that comes from within oneself without any coercion from outsiders.

3. Patience, an attitude that can control emotions in dealing with something.

4. Entrepreneurship, the soul that has creative and innovative ideas in creating and developing a business.

\section{Work Motivation}

Sakban et al. (2019) claims that motivation is a psychological trait that stimulates an individual's desire to engage in particular activities in order to reach a goal. So, according to this opinion, motivation is what is in someone who will actualize a behavior that is directed towards the goal of achieving the goal of satisfaction.

Sumardjo \& Priansa (2018) state that motivation is defined as a readiness to exert great effort to attain organisational goals, conditioned by the ability of efforts to meet specific human needs. Sumardjo and Priansa (2018) view motivation as a system consisting of: Needs; Encouragement, Incentive.

\section{Job Satisfaction}

Bintoro (2017) suggests that job satisfaction is an emotional attitude in which a person enjoys and loves his or her job. This approach is reflected in work morale, discipline, and work performance. Job satisfaction can be found at the workplace, outside of the workplace, or a mix of the two. With job satisfaction obtained, it is expected that employees can achieve high employee performance. Without job satisfaction, employees will work not as expected by the organisation, so as a result, employees' performance will be low, so that organisational goals will not be accomplished optimally.

\section{Employee Performance}

Zainal et al. (2019) suggest that performance is the consequence of work and work behavior that has been attained in performing the duties and obligations assigned in a specific 
period. Afandi (2018) argues the ability of employees to achieve particular abilities is employee performance.

According to Subyantoro \& Suwarto (2020) that the measurement of individual (employee) performance consists of six indicators:

1. Quality is measured by an employee's understanding of the quality and the improvement of the task regarding employee's skills and abilities.

2. Quantity shall be the amount generated and indicated in such respects as the number of units or the number of completed activity cycles.

3. Punctuality is the activity level finished at the start of the period specified for the outcome to be coordinated with and time available for other activities to be maximized.

4. Efficiency is maximized to enhance the results of each unit of resource consumption by using organisational resources (manufacturing, money, technology, raw materials).

5. Independence is an employee's level that can perform its duties.

6. Working commitment is a level in which employees undertake to work with the agency and the office obligations of the employee.

\section{Concetual Framework and Hypotesis}

Based on background study of theory and relevant research hence conceptual framework of this research is like picture. 1 below

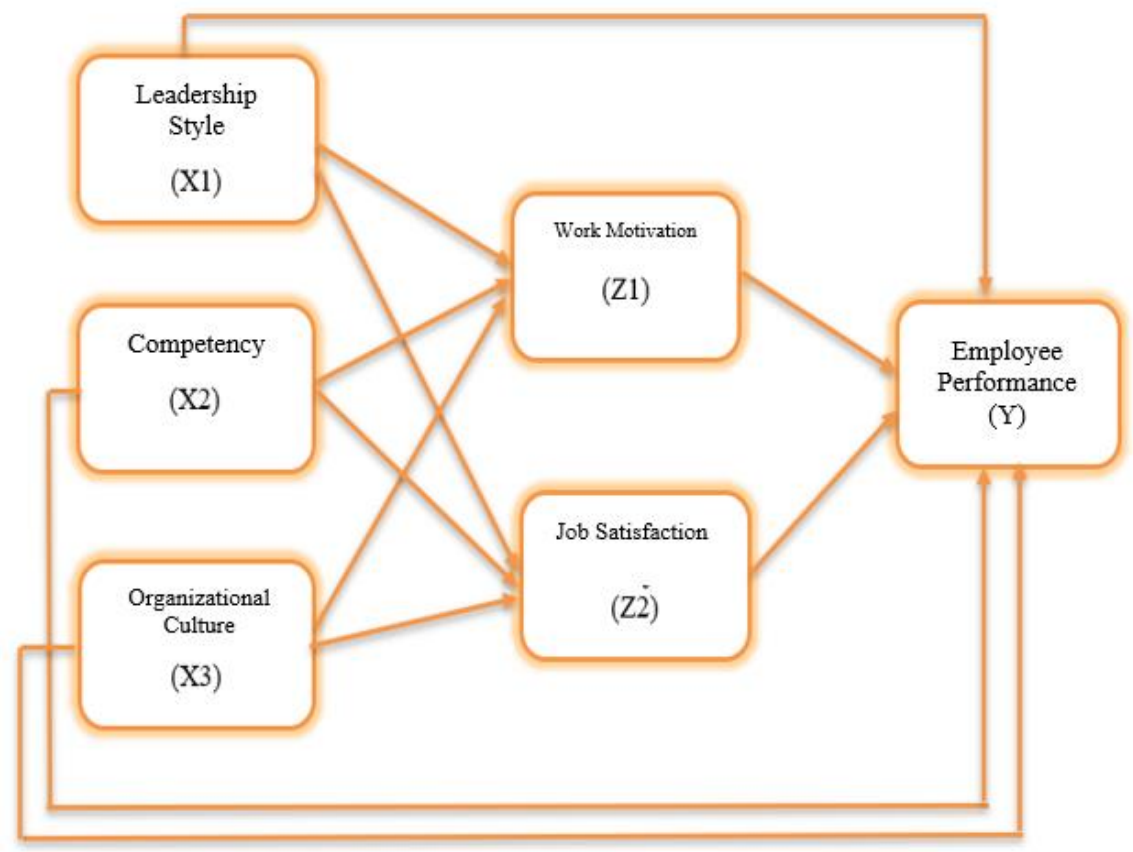

Picture 1. Conceptual Framework

Based on the theoretical framework and frame of mind, it can be arranged hypothesis of the study as follows $\mathrm{H} 1-\mathrm{H} 11$. 


\section{RESEARCH METHODS}

This research design used a quantitative approach. It used a purposive sampling method with certain considerations or criteria, namely for employees with more than 1-year working time. The number of samples using the slovin formula shall be determined. The total population in this study was 116 people. Through the calculation of the slovin formula, a sample of 90 employees was obtained.

The type of data used in this research was quantitative data. In contrast, the source of data used in this study was primary data. The data was obtained directly from respondents using a questionnaire and then converted into numbers using a Likert scale. The Likert scale had a gradient in the form of words between very positive and negative, including: (a). Strongly agree (SS) : Score 5, (b). Agree (S) : Score 4, (c). Neutral (N) : Score 3, (d). Disagree (TS) : Score 2, (d). Strongly disagree (STS): Score 1

In this study, the variables used were six variables that were analyzed to answer the problem formulation, which consisted of the variables of leadership style, competence, organizational culture, work motivation, job satisfaction, and employee performance.

The data analysis method used in this study was path analysis with the help of the SmartPLS program, which includes: (1) Outer model testing using: (a). Convergent Validity (b) Discriminant Validity by using average variance extracted (AVE). Composite reliability by using Cronbach's alpha. (2). Inner Model Analysis using R-square (3). Evaluation of Goodness of Fit. using R2, and Q2. (4). Hypothesis testing (resampling bootstrapping) with a comparison of tcount and t-table or alpha $5 \%$ with a significance value, and mediation test with Sobel test

The relationship or influence between variables as follows:

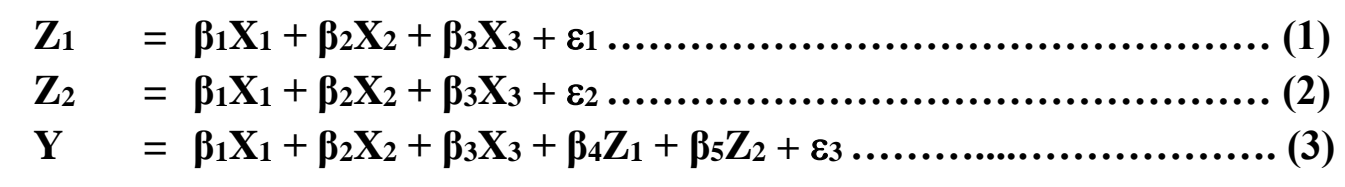

Information :

$\mathrm{Y}=$ Employee performance

$\mathrm{Z} 1$ = Work motivation

$\mathrm{Z} 2$ = Job Satisfaction

$\mathrm{X} 1$ = Leadership style

$\mathrm{X} 2=$ Competence

$\mathrm{X} 3$ = Organizational culture

$\beta_{1} \mathrm{~s} / \mathrm{d} \beta_{5}=$ Regression coefficient

$\varepsilon=$ Standard error

\section{Sobel Test Analysis}

The Sobel test employs the $\mathrm{z}$ test using the formula below: 


$$
z=\frac{a b}{\sqrt[a]{\left(b^{2} S E_{a}^{2}\right)+\left(a^{2} S E_{b}^{2}\right)}}
$$

Information:

$\mathrm{a}=$ The coefficient of regression of the independent variable on the mediating variable.

$b=$ The coefficient of regression of the mediating variable on the dependent variable.

Sea $=$ Standard error of estimation of the independent variable's influence on the mediating variable.

$\mathrm{SEb}=$ Standard error of estimation of the mediating variable's effect on the dependent variable.

\section{FINDINGS AND DISCUSSION}

\section{Measurement Model Analysis (Outer Model)}

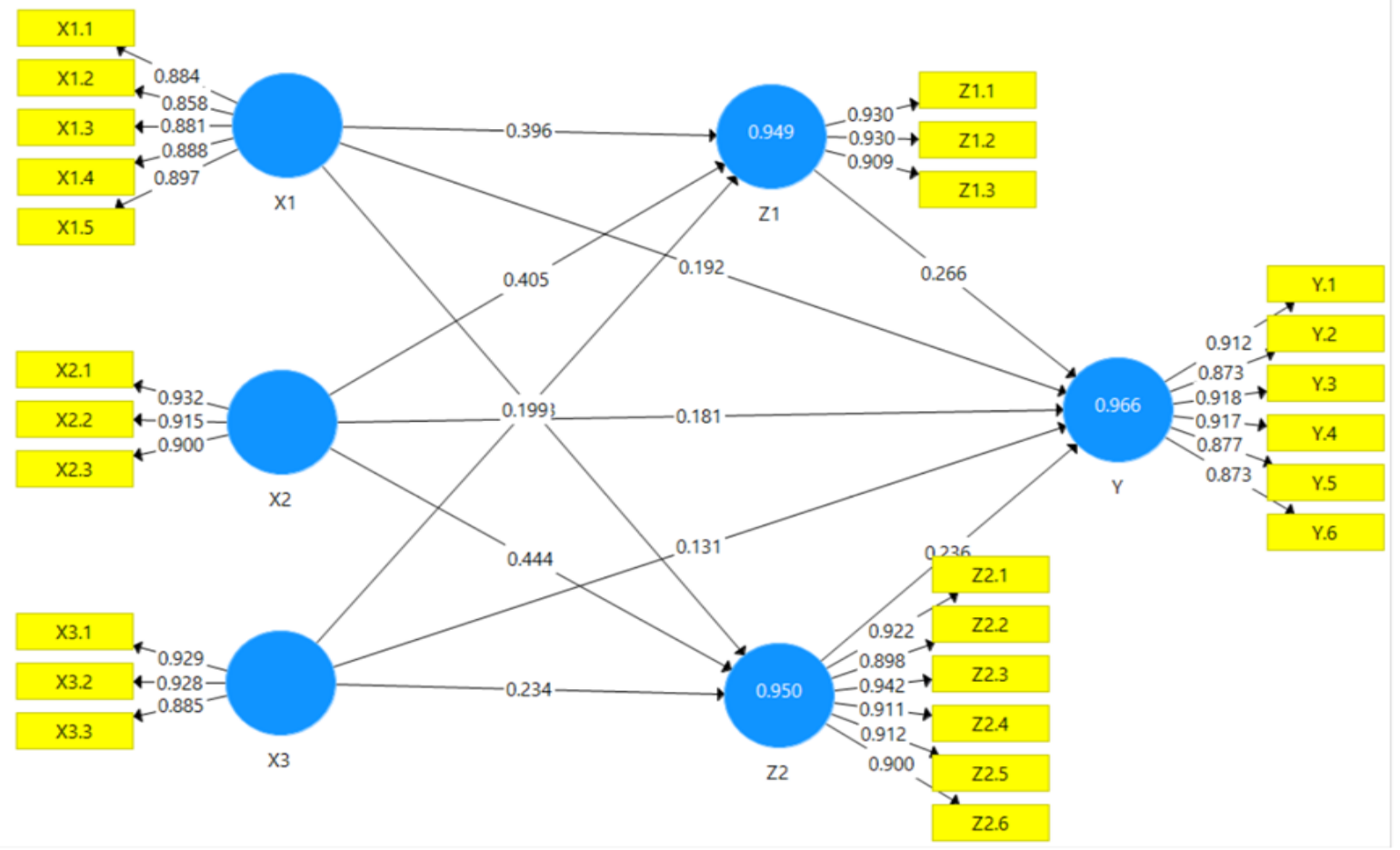

Source: Primary data processed, 2021

Picture 1 Algorithm with SmartPls 3.0 
Table 1

Outer Loading Result

\begin{tabular}{|c|c|c|c|c|}
\hline $\begin{array}{c}\text { Research } \\
\text { variable }\end{array}$ & Indicator & $S L F \geq 0,70$ & $\operatorname{AVE} \geq 0,50$ & Conclusion \\
\hline A. Leadership style & $\begin{array}{l}\mathrm{X} 1.1 \\
\mathrm{X} 1.2 \\
\mathrm{X} 1.3 \\
\mathrm{X} 1.4 \\
\mathrm{X} 1.5\end{array}$ & $\begin{array}{l}0,884 \\
0,858 \\
0,881 \\
0,888 \\
0,897\end{array}$ & 0,777 & $\begin{array}{l}\text { Valid } \\
\text { Valid } \\
\text { Valid } \\
\text { Valid } \\
\text { Valid }\end{array}$ \\
\hline B. Competence & $\begin{array}{r}X 2.1 \\
X 2.2 \\
X 2.3 \\
\end{array}$ & $\begin{array}{l}0,932 \\
0,915 \\
0,900 \\
\end{array}$ & 0,839 & $\begin{array}{l}\text { Valid } \\
\text { Valid } \\
\text { Valid } \\
\end{array}$ \\
\hline C. Organizational culture & $\begin{array}{l}X 3.1 \\
X 3.2 \\
X 3.3 \\
\end{array}$ & $\begin{array}{l}0,929 \\
0,928 \\
0,885\end{array}$ & 0,836 & $\begin{array}{l}\text { Valid } \\
\text { Valid } \\
\text { Valid }\end{array}$ \\
\hline D. Work motivation & $\begin{array}{l}\mathrm{Z} 1.1 \\
\mathrm{Z} 1.2 \\
\mathrm{Z} 1.3\end{array}$ & $\begin{array}{l}0,930 \\
0,930 \\
0,909\end{array}$ & 0,852 & $\begin{array}{l}\text { Valid } \\
\text { Valid } \\
\text { Valid }\end{array}$ \\
\hline E. Job Satisfaction & $\begin{array}{l}\text { Z2.1 } \\
\text { Z2.2 } \\
\text { Z2.3 } \\
\text { Z2.4 } \\
\text { Z2.5 } \\
\text { Z2.6 }\end{array}$ & $\begin{array}{l}0,922 \\
0,898 \\
0,942 \\
0,911 \\
0,912 \\
0,900\end{array}$ & 0,836 & $\begin{array}{l}\text { Valid } \\
\text { Valid } \\
\text { Valid } \\
\text { Valid } \\
\text { Valid } \\
\text { Valid }\end{array}$ \\
\hline F. Employee performance & $\begin{array}{l}\text { Y.1 } \\
\text { Y.2 } \\
\text { Y. } 3 \\
\text { Y.4 } \\
\text { Y.5 } \\
\text { Y. } 6\end{array}$ & $\begin{array}{l}0,912 \\
0,873 \\
0,918 \\
0,917 \\
0,877 \\
0,873\end{array}$ & 0,801 & $\begin{array}{l}\text { Valid } \\
\text { Valid } \\
\text { Valid } \\
\text { Valid } \\
\text { Valid } \\
\text { Valid }\end{array}$ \\
\hline
\end{tabular}

The outer loading test results in Table 1 demonstrate that the indicators of each research variable have a loading factor value larger than 0.70 and an AVE greater than 0.50, implying that the research indicators have convergent validity, which is adequate for measuring variables. latent. 
Table 2

Cronbach's Alpha and Composite Reliability

\begin{tabular}{|c|l|c|c|c|c|c|}
\hline No. & \multicolumn{1}{|c|}{$\begin{array}{c}\text { Research } \\
\text { variable }\end{array}$} & $\begin{array}{c}\text { Number of Indicators } \\
\text { Alpha }\end{array}$ & $\begin{array}{c}\text { Cronbach's } \\
\text { Reliability }\end{array}$ & $\begin{array}{c}\text { Composite } \\
\text { Thumb }\end{array}$ & $\begin{array}{c}\text { Rule of } \\
\text { Conclusion }\end{array}$ \\
\hline 1. & Leadership style & 5 & 0,928 & 0,946 & $>=0,70$ & Reliable \\
\hline 2. & Competence & 3 & 0,904 & 0,940 & $>=0,70$ & Reliable \\
\hline 3. & Organizational culture & 3 & 0,901 & 0,938 & $>=0,70$ & Reliable \\
\hline 4. & Work motivation & 3 & 0,913 & 0,945 & $>=0,70$ & Reliable \\
\hline 5. & Job Satisfaction & 6 & 0,961 & 0,968 & $>=0,70$ & Reliable \\
\hline 6. & Employee performance & 6 & 0,950 & 0,960 & $>=0,70$ & Reliable \\
\hline
\end{tabular}

Source: Primary data processed, 2021

Cronbach's alpha analysis yielded a range of 0.901-0.961 and composite reliability of 0.938-0.968, both of which were greater than 0.70 . This means that all indicators are accurate in measuring each variable.

Table 3

R square and Adjusted $R$ square

\begin{tabular}{|c|c|c|}
\hline & R Square & Adjusted R Square \\
\hline Job Satisfaction & 0.950 & 0.948 \\
\hline Employee performance & 0.966 & 0.964 \\
\hline Work motivation & 0.949 & 0.947 \\
\hline
\end{tabular}

Source: Primary data processed, 2021

Table 3 is the value of $\mathrm{R}$ square and Adjusted $\mathrm{R}$ square obtained from bootstrapping results in Smartpls 3.0. So, the Rsquare value of work motivation is $94.90 \%$ (0.949 x 100), $96 \%$ performance, $95 \%$ job satisfaction which is included in the strong category. Based on the results of the calculations above, the magnitude of Q2 is close to 1, meaning that the model that will be used in testing the hypothesis in this study has good predictive relevance so that the model used for hypothesis testing has a good goodness fit model. 


\section{Measurement Model Analysis (Inner Model)}

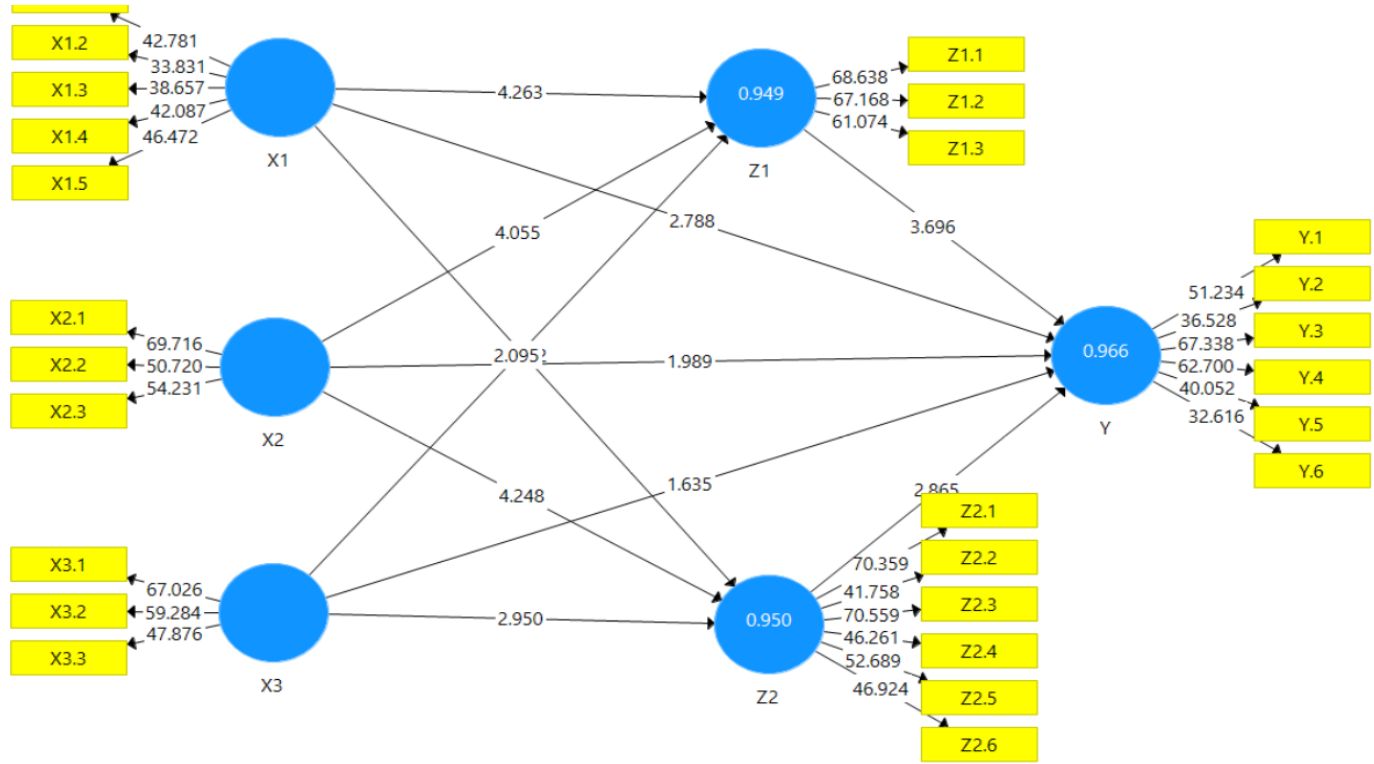

Source: Primary data processed, 2021

Picture 2 Bootstrapping result with SmartPls 3.0

Table 4. Summary of Research Hypothesis Testing Results

\begin{tabular}{|c|l|c|c|c|c|c|c|}
\hline No. & Research Hypothesis & $\begin{array}{c}\text { Direct } \\
\text { Influence }\end{array}$ & $\begin{array}{c}\text { Indirect } \\
\text { Influence }\end{array}$ & $\begin{array}{c}\text { Total } \\
\text { Influence }\end{array}$ & $\rho$ value & $\begin{array}{c}\text { Hypothesis } \\
\text { Test Results }\end{array}$ & Decision \\
\hline 1. & $\begin{array}{l}\text { Leadership style on } \\
\text { employee } \\
\text { performance }\end{array}$ & 0,192 & - & 0,192 & 0,006 & +/Significant & Accepted \\
\hline 2. & $\begin{array}{l}\text { Competence on } \\
\text { employee } \\
\text { performance }\end{array}$ & 0,181 & - & 0,181 & 0,047 & + +/Significant & Accepted \\
\hline 3. & $\begin{array}{l}\text { Organizational culture } \\
\text { on employee } \\
\text { performance }\end{array}$ & 0,131 & - & 0,131 & 0,103 & $\begin{array}{l}+/ \text { Sot } \\
\text { Significant }\end{array}$ & Rejected \\
\hline 4. & $\begin{array}{l}\text { Motivation on } \\
\text { employee } \\
\text { performance }\end{array}$ & 0,266 & - & 0,266 & 0,000 & + +/Significant & Accepted \\
\hline 5. & $\begin{array}{l}\text { Job satisfaction on } \\
\text { employee } \\
\text { performance }\end{array}$ & 0,236 & - & 0,236 & 0,004 & +/Significant & Accepted \\
\hline 6. & $\begin{array}{l}\text { Leadership style on } \\
\text { employee } \\
\text { performance through } \\
\text { work motivation }\end{array}$ & 0,192 & 0,105 & 0,297 & 0,0052 & + +/Mediate & Accepted \\
\hline
\end{tabular}




\begin{tabular}{|c|l|c|c|c|c|l|l|}
\hline 7. & $\begin{array}{l}\text { Competence on } \\
\text { employee } \\
\text { performance through } \\
\text { work motivation }\end{array}$ & 0,181 & 0,108 & 0,289 & 0,006 & +/Mediate & Accepted \\
\hline 8. & $\begin{array}{l}\text { Organizational culture } \\
\text { on employee } \\
\text { performance through } \\
\text { work motivation }\end{array}$ & 0,131 & 0,0529 & 0,184 & 0,068 & $\begin{array}{l}\text { +/Cannot } \\
\text { Mediate }\end{array}$ & Rejected \\
\hline 9. & $\begin{array}{l}\text { Leadership style on } \\
\text { employee } \\
\text { performance through } \\
\text { job satisfaction }\end{array}$ & 0,292 & 0,077 & 0,269 & 0,022 & +/Mediate & Accepted \\
\hline 10. & $\begin{array}{l}\text { Competence on } \\
\text { employee } \\
\text { performance through } \\
\text { job satisfaction }\end{array}$ & 0,181 & 0,105 & 0,286 & 0,017 & +/Mediate & Accepted \\
\hline 11. & $\begin{array}{l}\text { Organizational culture } \\
\text { on employee } \\
\text { performance through } \\
\text { job satisfaction }\end{array}$ & 0,139 & 0,056 & 0,187 & 0,039 & + +/Mediate & Accepted \\
\hline
\end{tabular}

Source: Primary Data, 2021

\section{The influence of leadership style on employee performance (H1)}

Based on table 4, regarding the path test that has been presented, the path coefficient value was 0.192. This shows that every one-point improvement in leadership style can be accompanied by an improvement in employees' performance at the Regional IV Office of BKN Makassar, which means the better the leadership style implemented during this time, it will increase employees' performance. Meanwhile, seen from t-count $=2.788$ and value $=0.006$, because the t-value is $2.788>1.96$ and value $=0.006<0.05$, According to the findings of this study, leadership style has a positive and substantial influence on employees' performance.

The data analysis results indicated that the leadership style established at BKN Makassar's Regional IV Office has a favorable and considerable influence on employees' performance. This finding validates Widodo, et.al (2017, p.260), prior findings, hence the hypothesis in this study that leadership style has a positive and significant impact on employees' performance is acceptable or provable.

\section{The Effect of Competence on Employee Performance (H2)}

Based on analysis of hypothesis testing in the study, it was obtained a coefficient value of 0.181 and with a value of $t$-count $=1.989$ and value $=0.047$, because with a $t$-count value of $1.989>1.96$ or a value of value $=0.047<0.05$, it can be interpreted that every increase of 1 competency points possessed by employees will be able to increase employees' performance by 
0.181 points. This can be interpreted that the higher the competence of employees, the higher the performance of employees.

From hypothesis testing seen from the t-count or value, It is possible to conclude that competence has a favorable and considerable impact on employees' performance at the Regional IV Office of BKN Makassar. This finding validates Aima, et. al., (2017), shows that employee competence can significantly improve employees' performance, so the hypothesis in this study that is competence has a positive and significant impact on employees' performance at the Regional IV Office of BKN Makassar can be proven or accepted.

\section{The influence of organisational culture on employee performance (H3)}

The results of testing the hypothesis in the study that is: from the coefficient value was 0.131 and with $\mathrm{t}$-count $=1.635$ and value $=0.103$, because with $\mathrm{t}$-count $1.635<1.96$ or value $=$ $0.103>0.05$, then organisational culture had a positive impact but not significant to increase workers' performance. Testing this hypothesis indicates that the organisational culture implemented by Regional IV Office of BKN Makassar was unable to improve the workers' performance. Judging from the respondent's answers when filling out the questionnaire, some employees did not have willingness in carrying out their work due to a lack of satisfaction with the workers' placement. This happened because they were not following their field of competence, and as a result, employees became impatient in carrying out their tasks and responsibility. Moreover, it needs the attention of the leadership in the office Regional IV Office of BKN Makassar to be able to build organisational culture, especially in terms of employee patience in providing services, this conclusion is obtained from Picture 1 cultural variable (X3) the lowest factor loading value is X3.3 $=0.885$ where the indicator is patience.

From the description above, it is possible to conclude that the research hypothesis organisational culture has a positive and considerable impact on employees' performance at the Regional IV Office of BKN Makassar cannot be proven or rejected.

\section{The effect of work motivation on employee performance $(\mathbf{H 4})$}

The value of the path coefficient in Smartpls 3.0 was 0.266 , This suggests that a onepoint boost in work motivation has the potential to improve employees' performance at the Regional IV Office of BKN Makassar by 0.266. This also implies that the greater the employee's work motivation, the greater the employee's performance. Thus, employee performance can be improved by the employees' motivation in carrying out the job. The hypothesis testing results in the study statistically showed t-count value of 3.696 and value $=0.000$, because the value of $t$ count $=3.696>1.96$ and value $=0.000<0.05$, then the data analysis in this study may demonstrate that work motivation has a positive and substantial influence on workers' performance, allowing the research hypothesis work motivation has a positive and constructive impact on employees' performance to be proven or accepted. 


\section{The effect of job satisfaction on employee performance (H5)}

The path coefficient value is 0.236 , which means that every one-point increase in employee job satisfaction, especially at the Regional IV Office of BKN Makassar, can improve employees' performance. This finding explains that the higher the satisfaction experienced by employees while working at BKN Makassar's Regional IV office, the better employee performance.

Furthermore, with $\mathrm{t}$-count $=2.865>1.96$ and value $=0.004<0.05$, This demonstrates statistically that there is a positive and significant relationship between work happiness and workers' performance. This research suggests that job satisfaction has a major impact on workers' performance. This study hypothesizes that work satisfaction has a positive and substantial impact on employees' performance can be proven or accepted.

6. The influence of leadership style on employee performance through work motivation (H6)

Based on the results of the online sobel test statistic, with the sobel test statistic value of $2.792>1.96$ and the value of $\rho$ value $=0.005<0.05$, this proves that work motivation can significantly mediate leadership style on employees' performance at Regional IV offices BKN Makassar, the reason is that both direct and indirect effects were significant. The data may demonstrate that the leadership style used by the Head of Regional IV Office of BKN Makassar would be able to boost employee motivation in carrying out their task, hence enhancing employees' performance. The research hypothesis, leadership style has a positive and substantial impact on performance through job motivation, was found to be acceptable.

\section{The influence of competence on employee performance through work motivation (H7)}

From the results of the online statistical test sobel, it showed that the sobel test value was $2.731>1.96$ and $\rho$ value $=0.006<0.05$, because the sobel test statistic value is larger than 1.96 and the $\rho$ value is smaller than 0.05 , this study can prove that work motivation can significantly mediate the influence of competence on employees' performance at the Regional IV office of BKN Makassar. The implications of this study show that with the competence possessed by each employee, it will be effective in motivating workers to work, which will then have an effect in enhancing employees' performance, particularly at the Regional IV Office of BKN Makassar. This study hypothesizes that competence has a positive and substantial impact on employees' performance through job motivation can be proven or accepted.

8. The influence of organisational culture on employee performance through work motivation (H8)

Based on the online Sobel test statistic results, it obtained the value as $1.822<1.96$ and pvalue $=0.068>0.05$, this implies that work motivation cannot mediate the influence of organisational culture on organisations' performance. This finding indicates that motivation in the form of support, needs, and incentives had not influenced organisational culture in the form of employees' patience, perseverance, and sincerity in providing services to increase employees' 
performance. Work motivation was not a moderator that influenced corporate culture and employee performance. Employee's performance at BKN Makassar's Regional IV office was unaffected by organisational culture, either directly or indirectly. The hypothesis that organisational culture has a positive and substantial impact on employees' performance through work motivation cannot be proven or rejected.

\section{The influence of leadership style on employee performance through job satisfaction (H9)}

The results of the Sobel test statistic regarding the influence of leadership style on employees' performance through job satisfaction, seen from the Sobel test statistic was $2.274>$ 1.96 and ovalue $0.022<0.05$. This indicates that job satisfaction can partially mediate the influence of leadership style on employees' performance, this finding indicated that the leadership style carried out by the Head of Regional IV Office of BKN Makassar has been able to provide job satisfaction for employees so that it had an impact on improving employees' performance. Thus, the hypothesis regarding the influence of leadership style has a positive and considerable impact on performance through job satisfaction can be proven or accepted.

\section{The influence of competence on employee performance through job satisfaction (H10)}

The results of the online sobel test statistic calculation, namely the influence of competence on employees' performance through job satisfaction, obtained a statistical test score $=2.375>1.96$ and ovalue $=0.0175<0.05$, this indicates that job satisfaction can partially mediate the effect of competence on the employees' performance at Regional IV Office of BKN Makassar. According to the research findings, employee competence may increase employees' performance if employees were satisfied while working work at BKN Makassar's Regional IV Office. Therefore, the hypothesis competence has a positive and substantial impact on employee performance mediated by job satisfaction, can be proven or accepted.

\section{The influence of organisational culture on employee performance through job satisfaction (H11)}

The results of the calculation of the sobel test statistic through online that the test statistic score $=2.055>1.96$ and besides that the $\rho v a l u e=0.039<0.05$, because the test statistic value $>$ 1.96 and besides the $\rho v a l u e=0.039<0.05$ means that the organisational culture that has been implemented so far has a substantial impact on employees' performance through job satisfaction. This finding indicates that the application of organisational culture that has been done thus far can boost employees' performance if workers were satisfied while working at BKN Makassar's Regional IV Office. Thus, the research hypothesis organisational culture has a positive and substantial impact on employees' performance through work satisfaction can be proven or accepted.

This article discusses the variables: Leadership Style, Competence, Organizational Culture, Work Motivation and Job Satisfaction. This article is in line with previous articles including: 
- Leadership Style: (Limakrisna et al., 2016), (Bastari et al., 2020), (Anwar et al., 2020), (Ali et al., 2016), (Djoko Setyo Widodo, P. Eddy Sanusi Silitonga, 2017), (Chauhan et al., 2019), (Elmi et al., 2016).

- Competence: (Riyanto, Pratomo, et al., 2017), (Purba et al., 2017).

- Organizational Culture: (Harini et al., 2020), (Elmi et al., 2016).

- Work Motivation: (Riyanto, Sutrisno, et al., 2017), (Bastari et al., 2020), (Prayetno \& Ali, 2017), (Rivai et al., 2017), (Chauhan et al., 2019), (Aima et al., 2017), and (Masydzulhak et al., 2016).

\section{CONCLUSION AND RECOMMENDATION}

Based on the results of the analysis and discussion offered in this study, the following conclusions can be presented: Empirical evidence suggests that leadership style and competence can have a considerable impact on employees' performance improvement. In the meanwhile, organisational culture is unlikely to have a substantial impact on employees' performance. The mediation test results indicated that leadership style and competence have a substantial impact on employees' performance through work motivation, however, organisational culture has no significant impact on employees' performance through motivation. Job satisfaction has a major influence on performance as a mediator of leadership style, competency, and organisational culture.

Suggestions or recommendations for Regional IV Office of BKN Makassar:

Organisational culture is not able to directly influence employees' performance but if it is mediated by job satisfaction, then organisational culture can have a significant impact on the performance of Regional IV Office of BKN Makassar employees. For future research, it is necessary to add respondents as research samples; this is intended to obtain better research results than those found by researchers.

\section{REFERENCE}

Adam, F. dan Jeny, Kamase. (2019). The Effect Competence and Motivation to Satisfaction and Performance. International Journal of Scientific \& Technology Research, 8(03).

Ali, A., Bin, L. Z., Piang, H. J., \& Ali, Z. (2016). The impact of motivation on the employee performance and job satisfaction in it park (software house) sector of Peshawar, Pakistan. International Journal of Academic Research in Business and Social Sciences, 6(9), 297310.

Afandi, P. (2018). Manajemen Sumber Daya Manusia (Teori, Konsep dan Indikator). Riau: Zanafa Publishing.

Andi, A., Sudarno, S., \& Nyoto, N. (2019). PENGARUH BUDAYA ORGANISASI, MOTIVASI KERJA, DAN KOMITMEN ORGANISASI TERHADAP KEPUASAN KERJA DAN KINERJA KARYAWAN PT. ARTA BOGA CEMERLANG PEKANBARU. Kurs: Jurnal Akuntansi, Kewirausahaan Dan Bisnis, 4(1), 59-70.

Aprikristanti, R. E. (2020). PENGARUH BUDAYA ORGANISASI DAN KOMPETENSI TERHADAP KINERJA MELALUI MOTIVASI PEGAWAI NEGERI SIPIL DI DINAS 
PENDIDIKAN KABUPATEN PROBOLINGGO. PROSIDING SEMINAR NASIONAL, 1(01), 93-110.

Aima, P. H., Adam, R., \& Ali, P. H. (2017). Model of Employee Performance : Competence Analysis and Motivation (Case Study at PT. Bank Bukopin, Tbk Center). Journal of Research in Business and Management.

Ali, H., Mukhtar, \& Sofwan. (2016). Work ethos and effectiveness of management transformative leadership boarding school in the Jambi Province. International Journal of Applied Business and Economic Research.

Anwar, K., Muspawi, M., Sakdiyah, S. I., \& Ali, H. (2020). The effect of principal's leadership style on teachers' discipline. Talent Development and Excellence.

Bastari, A., -, H., \& Ali, H. (2020). DETERMINANT SERVICE PERFORMANCE THROUGH MOTIVATION ANALYSIS AND TRANSFORMATIONAL LEADERSHIP. International Journal of Psychosocial Rehabilitation. https://doi.org/10.37200/ijpr/v24i4/pr201108

Bintoro, D. (2017). Manajemen penilaian kinerja karyawan. Yogyakarta: Gava Media.

Busro, M. (2018). Teori-teori manajemen sumber daya manusia. Prenada Media.

Chauhan, R., Ali, H., \& Munawar, N. A. (2019). BUILDING PERFORMANCE SERVICE THROUGH TRANSFORMATIONAL LEADERSHIP ANALYSIS, WORK STRESS AND WORK MOTIVATION (EMPIRICAL CASE STUDY IN STATIONERY DISTRIBUTOR COMPANIES). Dinasti International Journal of Education Management And Social Science. https://doi.org/10.31933/dijemss.v1i1.42

Deswarta, D. (2017). PENGARUH KOMPETENSI DAN MOTIVASI TERHADAP KEPUASAN KERJA DAN KINERJA DOSEN FAKULTAS TARBIYAH DAN KEGURUAN UIN SULTAN SYARIF KASIM RIAU. VALUTA, 3(1), 19-39.

Djoko Setyo Widodo, P. Eddy Sanusi Silitonga, \& H. A. (2017). Organizational Performance : Analysis of Transformational Leadership Style and Organizational Learning. Saudi Journal of Humanities and Social Sciences. https://doi.org/10.21276/sjhss.2017.2.3.9

Edison, E., Anwar, Y., \& Komariyah, I. (2016). Manajemen sumber daya manusia. Bandung: Alfabeta.

Elmi, F., Setyadi, A., Regiana, L., \& Ali, H. (2016). Effect of leadership style, organizational culture and emotional intelligence to learning organization: On the Human Resources Development Agency of Law and Human Rights, Ministry of Law and Human Rights. International Journal of Economic Research.

Ezeanyim, E. E., \& Ufoaroh, E. T. (2019). The Impact of Job Satisfaction on Employee Performance in Selected Public Enterprise in Awka, Anambra State. Global Journal of Management And Business Research.

Gunawan. (2019). Pengaruh Kompetensi Terhadap Kinerja Pegawai dan Motivasi Sebagai Variabel Intervening Pada Kantor UPTD Penda-patan Wilayah I Palu. E-Jurnal Katalogis,3(1).

Harini, S., Hamidah, Luddin, M. R., \& Ali, H. (2020). Analysis supply chain management factors of lecturer's turnover phenomenon. International Journal of Supply Chain Management.

Hasmin, E. (2016). Pengaruh Budaya Organisasi Terhadap Kinerja Pegawai Di Kantor Sekretariat Daerah (Setda) Kota Tarakan. Jurnal Ilmiah Bongaya, 41-47. 
Haqq, Najmi (2016). Pengaruh Budaya Organisasi Terhadap Kinerja Karyawan Melalui Motivasi SebagaiVariabel Intervening Studi pada PT. Rahmat Jaya Perkasa Sidoarjo. Bisma (Bisnis dan Manajemen), 9(1) Oktober 2016.

Himawan, Ilham., Taba, M.Indrus., Reni, Andi (2019). The Effect of Leadership Style and Organizational Culture on Employee Performance Through Job Satisfaction as Variablei at Telkom Indonesia Regional VII Division. Hasanuddin Journal of Business Strategy (HJBS). HJBS Vol.1 No.3 Juli 2019

Khair, H. (2019). Pengaruh Kepemimpinan Dan Kompensasi Terhadap Kepuasan Kerja Melalui Motivasi Kerja. Maneggio: Jurnal Ilmiah Magister Manajemen, 2(1), 69-88.

Limakrisna, N., Noor, Z. Z., \& Ali, H. (2016). Model of employee performance: The empirical study at civil servants in government of west java province. International Journal of Economic Research.

Masydzulhak, P. D., Ali, P. D. H., \& Anggraeni, L. D. (2016). The Influence of work Motivationand Job Satisfaction on Employee Performance and Organizational Commitment Satisfaction as an Intervening Variable in PT. Asian Isuzu Casting Center. In Journal of Research in Business and Management.

Moeljahwati, E., \& Yandono, P. E. (n.d.). PENGARUH BUDAYA ORGANISASI DAN MOTIVASI KERJA TERHADAP KINERJA PEGAWAI MELALUI KEPUASAN KERJA PEGAWAI.

Mulyadi, D. (2015). Perilaku organisasi dan kepemimpinan pelayanan. Bandung: Alfabeta.

Nurwijayanti., Hamzah, D. dan Hamid, N (2019). Pengaruh Gaya Kepemimpinan dan Lingkungan Kerja Terhadap Kinerja Pegawai Melalui Kepuasan Kerja Sebagai Variabel Intervening Pada PT. Wedu Kabupaten Merauke. Hasanuddin Journal of Applied Business and Entrepreneurship, Vol.2 No.1 Januari 2019

Prayetno, S., \& Ali, H. (2017). Analysis of advocates organizational commitment and advocates work motivation to advocates performance and its impact on performance advocates office. International Journal of Economic Research.

Prahasti, S., \& Wahyono, W. (2018). PENGARUH GAYA KEPEMIMPINAN, BUDAYA ORGANISASI, DAN LINGKUNGAN KERJA TERHADAP KINERJA PEGAWAI DENGAN KEPUASAN KERJA SEBAGAI MEDIATOR. Economic Education Analysis Journal, 7(2), 543-552.

Purba, C. B., Arzio, \& Ali, H. (2017). The influence of compensation, working environment and organization culture on working productivity of BPJS (workers social security agency) employment staff in Rawamangun Branch. Man in India.

Raisid, I. A., Lestari, H., \& Rostyaningsih, D. (2015). Pengaruh Kepemimpinan Dan Kompetensi SDM Terhadap Kinerja Pegawai Inspektorat Jenderal Kementerian Pendidikan Dan Kebudayaan Jakarta. Journal of Public Policy and Management Review, 5(1), 102-111.

Rathore, K., Khaliq, C. A., \& Aslam, N. (2017). The Influence of Leadership Styles on Employees Performance under Perceptions of Organizational Politics: A Study of Telecom Sector in Pakistan. International Journal of Management Research and Emerging, 7(1), 106-140.

Renyut, Bernard.C., Moding, H.B., Bima. J. dan Sukmawati, ST. (2017). The Effect of Organizational Commitment, Competence on Job Satisfaction and Employees 
Performance in Maluku Governor's Office. IOSR Journal of Business and Management, Volume 19, Issue 11. Ver.III (November. 2017), PP 18-29 www.iosrjournals.org.

Rivai, V., \& Mulyadi, D. (2012). Kepemimpinan dan Perilaku Organisasi edisi ketiga. Jakarta: PT. Rajagrafindo Persada.

Riyanto, Setyo, Sutrisno, Ady, Ali, Hapzi (2017). The Impact of Working Motivation and Working Environment on Employees Performance in Indonesia Stock Exchange, International Review of Management and Marketing International Review of Management and Marketing | Vol $7 \bullet$ Issue 3

Robbins, S. P., \& Judge, T. A. (2015). Perilaku organisasi: Konsep kontroversi, Applikasi, Alih Bahasa Hadayana Pujaatmuka dan Benyamin Molan. Edisi Kedelapan. JILID II. Penerbit Prenhalindo. Jakarta.

Sakban, S., Nurmal, I., \& Ridwan, R. B. (2019). Manajemen sumber daya manusia. Alignment: Journal of Administration and Educational Management, 2(1), 93-104.

Saputri, R., \& Andayani, N. R. (2018). Pengaruh Kepemimpinan dan Motivasi Kerja terhadap Kinerja Pegawai pada Departemen Production di PT Cladtek Bi-metal Manufacturing Batam. Journal of Applied Business Administration, 2(2), 307-316.

Sedarmayanti, H. (2018). Manajemen Sumber Daya Manusia; Reformasi Birokrasi dan Manajemen Pegawai Negeri Sipil. Reflika Aditama.

Silitonga, P. E. S., Widodo, D. S., \& Ali, H. (2017). Analysis of the effect of organizational commitment on organizational performance in mediation of job satisfaction (Study on

Subyantoro, A., \& Suwarto, F. X. (2020). Manajemen Sumber Daya Manusia Strategi. Penerbit Andi.

Sudarsono, Bambang. (2014) Analisis Budaya Organisasi Dan Komitmen Organisasional Terhadap Kepuasan Kerja Melalui Motivasi (Studi Pada Dosen Politeknik Negeri Semarang). Jurnal Fokus Ekonomi, Vol. 9 No. 1.

Sumardjo, M., \& Priansa, D. J. (2018). Manajemen Pengembangan Sumber Daya Manusia: Konsep-konsep Kunci. Cetakan Pertama. Penerbit Alfabeta. Bandung.

Usman, F. (2019). Pengaruh kecerdasan emosi dan budaya organisasi terhadap kinerja melalui kepuasan sebagai variabel intervening. Forum Ekonomi, 21(2), 132-142.

Wibowo, W., \& Phil, M. (2016). Budaya Organisasi; Sebuah Kebutuhan untuk Meningkatkan Kinerja Jangka Panjang. Jakarta: PT Raja Grafindo Persada.

Yusniar, Y. (2016). Pengaruh Budaya Organisasi Terhadap Kinerja Melalui Motivasi di Sekretariat Daerah Kabupaten Aceh Utara. E-Mabis: Jurnal Ekonomi Manajemen Dan Bisnis, 17(1), 85-104.

Zainal, V. R., Ramly, H. M., Mutis, T., \& Arafah, W. (2019). Manajemen sumber daya manusia untuk perusahaan dari teori ke praktik. 